\title{
EFFECT OF IRRIGATION WATER AND NITROGEN FERTILIZER ON GROWTH AND PRODUCTIVITY OF COWPEA CROP WITH MAGNETIZED WATER
}

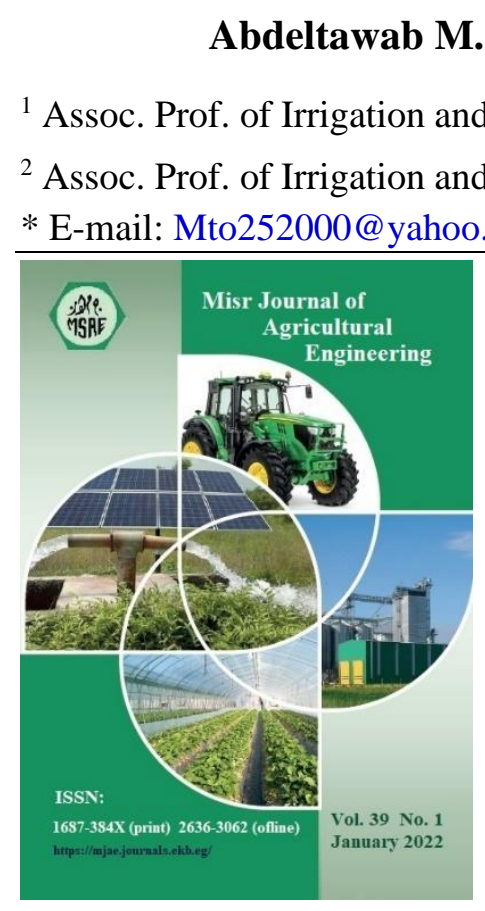

(C) Misr J. Ag. Eng. (MJAE)

\section{Keywords:}

Magnetized water; Water quality; Cowpea; Growth parameters; Water and Nitrogen use efficiency.

\section{ABSTRACT}

Using of magnetized water has shown several advantages including improvement quality of irrigation water and increase the productivity of vegetable crops. Therefore, the present work was carried out to study the response of growth, yield, water and nitrogen use efficiency of cowpea for irrigation with two types of irrigation water (magnetized and non-magnetized water) under two levels of nitrogen fertilizer (100 and $75 \%$ of the recommended rate) during the summer seasons of 2018 and 2019. The results cleared that all yield parameters increased significantly when irrigation occurred using magnetic water, such as total yield which increased by about 26 and $31 \%$ in the first and second season, respectively. Concerning the effects of magnetized water, the results reflected that irrigation with magnetic water significantly increased the values of the water use efficiency from 0.40 and $0.42 \mathrm{~kg} / \mathrm{m}^{3}$ to 0.52 and $0.54 \mathrm{~kg} / \mathrm{m}^{3}$ with magnetic water in both growing seasons. The gradual increases of nitrogen fertilizer levels were accompanied with significant increases on vegetative growth and yield, as well as nitrogen uptake and nitrogen use efficiency. The interaction effects between types of irrigation water and different levels of nitrogen fertilizer significantly affected all treatments and reflected a positive impact. The results reflect the possibility of reducing the applied rate of nitrogen fertilizer when cowpea plants irrigated with magnetized water to a percentage $25 \%$ without affecting the different studied characters. As well as many benefits for cowpea plants such as enhancing vegetative growth, increasing yield, improving crop quality were achieved.

\section{INTRODUCTION}

$\mathrm{M}$ agnetized water technology is non-chemical method and an environmental friendly way to get high yields of crops. Such technologies don't cause any soil degradation due to salinity and do not pollute the environment. Magnetic water treatment enhances both crop productivity and quality. Also, it leads to an efficient use of arable land by using water resources available for crop production (Hozayn et al., 2011 and Texeira and Dobranszki, 2014). When water passes through a magnetic field, its structure and some 
physical properties such as density, salt solution capacity and deposition ratio of solid particles are changed (Ali et al., 2014). The magnetic treatment of water reduces the surface tension, which increases the solubility of water-soluble minerals such as calcium, nitrogen, potassium, iron, and lead, which can enhance the absorption of nutrients by crop roots (Selim, 2008 and Maheshwari and Grewal, 2009). Omid, 2016 reported that plant growth increased significantly with magnetized water by $23 \%$ compared to control. Moussa (2011) found that the used magnetic water can increase parameters with the bean yield. Yadollahpour et al. (2014) indicated that magnetic treated of irrigation water were significant in yield. Amer et al. (2014) found that irrigation of soybean plant by magnetic water significantly increased the seed weight, no of pods/ plant, no of branch/plant, seeds weight/plant, and weight of pods/plant as compared to untreated plants.

Furthermore, several studies have shown that magnetic treatment of irrigation water offers many benefits in agriculture such as enhancing vegetative growth, increasing yield as well as early yield of crops, improving crop quality, increasing fertilizer efficiency and reducing the cost of farm operations (Maheshwari and Grewal, 2009). Magnetized water technique may allow for the optimization of water productivity or increasing water use efficiency (WUE) by improving crop yield and quality.

In Egypt, area planted of cowpea according to Agricultural Economic Bulletin, in 2013 was about 14830 feddan with production 17248 tons and an average yield of 1.163 ton/feddan (Bashandy and El- Shaieny, 2016). Cowpea is source of vitamins, minerals, carbohydrates and dietary fibers (Gonçalves et al., 2016). Cowpea using as forage it is a source of protein and is quite digestible for ruminants (Anele et al., 2011). Plant nutrition using optimum quantity of chemical fertilizer is one of the most important factors that needed for plant growth and productivity. Nitrogen is the most recognized in plant for its presence in the structure of the protein molecule. Accordingly, $\mathrm{N}$ plays an important role in synthesis of the plant constituents through the action of different enzymes (Sainju et al., 2003).

Farmers' dependence on the use of chemical fertilizers in large quantities leads to increased production costs, environmental pollution and production of unhealthy food, which contaminated with chemical residual effects. Therefore, it is very important to use modern technologies that reduce the use of chemical fertilizers without negatively affecting the yield. Magnetized water technology is one of these techniques. Accordingly, this study aimed to determine the effect of magnetized water irrigation on the possibility of reducing the rates of chemical nitrogen fertilizer necessary for the optimal growth and yield of cowpea crop. It will be followed by reducing production costs in addition to reducing environmental pollution resulting from the excessive use of such fertilizers. As well as studying the interaction between the aforementioned treatments to reach the highest value of the crop in terms of quantity and quality and studying their effect on the characteristics of vegetative growth and yield.

The objectives of this research were to: (1) evaluate the response growth and yield of cowpea crop for irrigation with two types of irrigation water (magnetized and non-magnetized water) under two levels of nitrogen fertilizer (100 and $75 \%$ of the recommended rate), (2) determine the response of water use efficiency (WUE, \%) and nitrogen use efficiency (NUE, \%) of cowpea for irrigation with two types of irrigation water (magnetized and non-magnetized 
water) under two levels of nitrogen fertilizer and (3) determine the best irrigation regime to achieve improvement of irrigation water quality and increase the productivity of cowpea crop.

\section{Experimental site:}

\section{MATERIALS AND METHODS}

In the present search, two experimental field were carried out during the summer seasons of 2018 and 2019 in sandy soil at the Experimental Farm of Soils and Water Research Department, Nuclear Research Center, Atomic Energy Authority, Cairo, Egypt, $30^{\circ} 24^{\prime} \mathrm{N}$ latitude, $31^{\circ} 35^{\circ} \mathrm{E}$ longitude, while the altitude is $20 \mathrm{~m}$ above the sea level. Preliminary to each experiment, soil samples from surface and subsurface layers $(0-60 \mathrm{~cm})$ of the experimental site were taken randomly and prepared for soil analysis according to the procedures described by Page et al. (1982). The bulk density of soil was determined using undisturbed soil cores according to Klute (1986). The mechanical and chemical analysis of the experimental soil are presented in Tables 1 and 2.

Table 1: Physical characteristics of the experimental soil.

\begin{tabular}{|c|c|c|c|c|c|c|c|}
\hline \multirow{2}{*}{$\begin{array}{c}\text { Soil } \\
\text { depth } \\
(\mathrm{cm})\end{array}$} & \multicolumn{3}{|c|}{$\begin{array}{c}\text { Particle size distribution } \\
(\%)\end{array}$} & \multirow{2}{*}{$\begin{array}{l}\text { Texture } \\
\text { class }\end{array}$} & \multirow{2}{*}{$\begin{array}{l}\text { Bulk density } \\
\quad\left(\mathrm{g} / \mathrm{cm}^{3}\right)\end{array}$} & \multirow{2}{*}{$\begin{array}{l}\text { F. C } \\
(\%)\end{array}$} & \multirow{2}{*}{$\begin{array}{l}\text { PWP } \\
(\%)\end{array}$} \\
\hline & Sand & Silt & Clay & & & & \\
\hline $0-15$ & 98.13 & 1.40 & 0.47 & \multirow{4}{*}{ Sand } & 1.37 & 9.2 & 2.1 \\
\hline $15-30$ & 98.73 & 0.80 & 0.47 & & 1.63 & 8.6 & 1.8 \\
\hline $30-45$ & 98.60 & 0.87 & 0.53 & & 1.67 & 8.6 & 1.8 \\
\hline $45-60$ & 98.63 & 0.87 & 0.50 & & 1.64 & 8.6 & 2.0 \\
\hline
\end{tabular}

Table 2: Chemical characteristics of the experimental soil.

\begin{tabular}{|c|c|c|c|c|c|c|c|c|c|c|}
\hline \multirow{2}{*}{$\begin{array}{l}\text { C.E.C } \\
\mathrm{Mol} / \mathrm{kg}\end{array}$} & \multirow{2}{*}{$\begin{array}{l}\mathrm{P}^{\mathrm{H}} \\
1: 2.5\end{array}$} & \multirow{2}{*}{$\begin{array}{l}\mathrm{EC} \\
(\mathrm{dS} / \mathrm{m}) \\
\text { at } 25^{\circ} \mathrm{c}\end{array}$} & \multicolumn{4}{|c|}{$\begin{array}{l}\text { Soluble anions } \\
(\mathrm{meq} / 1)\end{array}$} & \multicolumn{4}{|c|}{$\begin{array}{l}\text { Soluble cations } \\
(\mathrm{meq} / 1)\end{array}$} \\
\hline & & & $\mathrm{CO}_{3}^{-}$ & $\mathrm{HCO}_{3}^{-}$ & $\mathrm{Cl}^{-}$ & $\mathrm{SO}_{4}^{--}$ & $\mathrm{Ca}^{++}$ & $\mathrm{Mq}^{++}$ & $\mathrm{Na}^{+}$ & $\mathrm{K}^{+}$ \\
\hline 9.3 & 8.1 & 0.69 & - & 2.1 & 2.0 & 2.0 & 1.8 & 0.8 & 3.1 & 0.4 \\
\hline
\end{tabular}

Seeds of cowpea (Vigna unguiculata L.) c.v. Kafr Elsheikh 1, provided by Field Crops Research Institute, Agricultural Research Center, Egypt, were sown on the $1^{\text {st }}$ of May 2018 and 2019 where $25 \mathrm{~kg}$ seeds/fed were used. Three coated seeds were sown in a hole with depth of $4 \mathrm{~cm}$. The distance between each two holes was $30 \mathrm{~cm}$. After 30 days from sowing, seedling in each hole was thinned to one plant per hole. The crop was harvested on 10 August 2018 and 2019. (100 days from sowing). The experiments were carried out during the growth seasons of 2018 and 2019 using surface drip irrigation system with built in drip line emitter (GR) at $30 \mathrm{~cm}$ spacing with manufacturing discharge $4 \mathrm{~L} / \mathrm{hr}$ and crop rows with $80 \mathrm{~cm}$ distance between each other.

\section{Magnetized water device and nitrogen fertilizer treatments:}

The magnetization device is a magnetic rod of 2 inches in diameter, with a magnetic capacity of 14.500 Gauss. This device was obtained by cooperation with the Delta Water Company for Magnetic Water Devices. The magnetized water was obtained by passing water through a magnetizing device fixed to the main irrigation pipeline, magnetizing device as shown in Pic.1. When water passes through the magnetic field it becomes magnetized, which causes some physical changes to the composition and shape of water molecules. Two types of 
irrigation water (magnetized and non-magnetized water) and two levels of $\mathrm{N}$ chemical fertilizer (100 and $75 \%$ of the recommended rate) were used. The chemical characteristics of the two types of irrigation water are shown in Table 3.

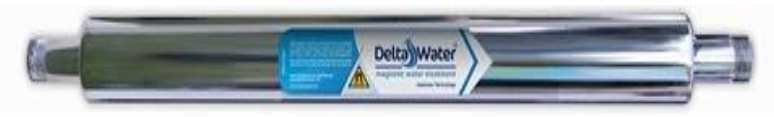

Pic. 1. The magnetization device used in the experiment.

The magnetization device was installed on a separate irrigation line to control the transit of treated water to the main experimental units treated with magnetized water. All experimental units received the type of water specified for irrigation between magnetized and nonmagnetized water by control valves on the main experimental units. The two levels of $\mathrm{N}$ fertilizer were $75 \%$ and $100 \%$ of the recommended rate.

Table 3: Chemical characteristics of irrigation water (magnetized and non-magnetized water).

\begin{tabular}{ccc}
\hline Water parameters & Non-magnetic & Magnetic \\
\hline pH & 8.60 & 8.47 \\
\hline EC & $0.40 \mathrm{dS} / \mathrm{m}$ & $0.35 \mathrm{dS} / \mathrm{m}$ \\
\hline $\mathbf{D . O}^{*}$ & $6.26 \mathrm{mq} / 1$ & $20.23 \mathrm{mq} / 1$ \\
\hline $\mathbf{H C O}_{3}^{-}$ & $2.91 \mathrm{mq} / 1$ & $2.78 \mathrm{mq} / 1$ \\
\hline $\mathbf{C l}^{-}$ & $0.52 \mathrm{mq} / 1$ & $0.43 \mathrm{mq} / \mathrm{l}$ \\
\hline $\mathbf{S O}_{4}^{--}$ & $0.92 \mathrm{mq} / 1$ & $0.95 \mathrm{mq} / 1$ \\
\hline $\mathbf{N a}^{+}$ & $2.82 \mathrm{mq} / 1$ & $2.41 \mathrm{mq} / 1$ \\
\hline $\mathbf{K}^{+}$ & $0.25 \mathrm{mq} / 1$ & $0.25 \mathrm{mq} / 1$ \\
\hline
\end{tabular}

* Dissolved Oxygen

The recommended doses of $100 \%$ NPK were $(200 \mathrm{~kg}$ ammonium sulphate $+200 \mathrm{~kg}$ calcium super phosphate $+100 \mathrm{~kg}$ potassium sulphate) according to Egyptian Ministry of Agriculture and Land Reclamation 2019, So that the levels of $\mathrm{N}$ fertilizer for cowpea production were $100 \% \mathrm{~N}$ (equal to $200 \mathrm{~kg}$ ammonium sulphate) and $75 \% \mathrm{~N}$ (equal to $150 \mathrm{~kg}$ Ammonium sulphate). Nitrogen fertilizer rates were divided into three doses distributed along three months of plant growth using drip fertigation system. All agricultural practices such as irrigation, weeding and controlling of pest and disease were applied as commonly recommended in cowpea production under drip irrigation conditions for all experimental treatments according to the recommendations of the Egyptian Ministry of Agriculture.

\section{The experimental Design:}

The experimental layout was arranged in a randomized complete block design with three replications. Type of irrigation water (magnetized and non-magnetized) and $\mathrm{N}$ treatments (two levels) were randomly allocated to the main plot and sub-plots, respectively. All experimental treatments were replicated three times. The experimental unit consists of 2 types of irrigation water x 2 nitrogen fertilizer rates $\mathrm{x} 3$ replicates which equal 12 plots. The experimental area of $336 \mathrm{~m}^{2}$ was divided into two sections represent the two irrigation water treatments. Each section includes 6 plots with $28 \mathrm{~m}^{2} /$ plot. 


\section{Plant measurements:}

The following growth parameters were determined: shoot length $(\mathrm{cm})$, root length $(\mathrm{cm})$, root dry weight (g), shoot dry weight (g), $\mathrm{N}$ uptake (mg/plant), nitrogen use efficiency (NUE, \%) and crop yield ( $\mathrm{kg} / \mathrm{ha})$.

\section{Water use efficiency (WUE):}

Water use efficiency values for the tested treatments were calculated according to Zhang et al. (2005), as follows:

$$
W U E=\frac{\text { yield }(Y)}{\text { seasonal crop evapotranspiration }\left(E T_{c}\right)}
$$

Where: WUE: Water use efficiency $\left(\mathrm{kg} / \mathrm{m}^{3}\right)$, Y: Yield $(\mathrm{kg} / \mathrm{ha})$, ETc: Seasonal crop evapotranspiration $\left(\mathrm{m}^{3} / \mathrm{ha}\right)$.

\section{Nitrogen use efficiency (NUE):}

Nitrogen use efficiency values for the tested treatments were estimated using the following equations:

$\mathrm{N}$ use efficiency $=\mathrm{N}$ uptake by plant/ (fertilizer $\mathrm{N}-$ residual fertilizer $\mathrm{N}$ in soil), it can also be described: $\mathrm{N}$ use efficiency $=\mathrm{N}$ uptake by plant/ ( $\mathrm{N}$ uptake by plant $+\mathrm{N}$ loss) (Wang and Zhou, 2014).

\section{Statistical Analysis:}

The obtained data were statistically analyzed using the analysis of variance method according to Waller and Duncan (1969). Duncan's multiple range tests at 5\% level of probability was used to compare the treatment means.

\section{RESULTS AND DISCUSSION}

\section{Growth parameters:}

The impact of irrigation with magnetized water under different levels of $\mathrm{N}$ fertilizers and their interactions on the vegetative growth characters of cowpea plants in seasons of 2018 and 2019 are presented in Table 4. Regarding the effect of types of irrigation water (magnetized and non-magnetized water), the obtained results indicate that irrigation with magnetic water under different levels of $\mathrm{N}$ fertilizers significantly increased all vegetative growth parameters; shoot length $(\mathrm{cm})$, root length $(\mathrm{cm})$, root dry weight $(\mathrm{g})$, shoot dry weight $(\mathrm{g})$, and crop yield $(\mathrm{kg} / \mathrm{ha})$ compared with the irrigation with non-magnetic water in both seasons. The percentage of increment in the different vegetative growth characteristics was recorded at rates ranging from $14.5 \%$ to $17 \%$ for shoot length and root length in the first and second seasons, respectively as shown in Table 4. These results agree with those obtained by Sadeghipour et al. (2013) and Shahin and Mashhour (2016), on cowpea and cucumber plants. Also, similar results recorded by Shedeed et. al. (2009), Yusuf and Ogunlela (2015 and 2017 a \& b) and Dawa et. al. (2017) on tomato plants, respectively. Generally, a similar effect for magnetic treatment was reported by Maheshwari and Grewal (2009). They concluded that the highest values of vegetative growth characteristics for some vegetable crops, were recorded when plants irrigated with magnetized water as compared with those plants irrigated with untreated water. In this respect, the stimulatory impact of magnetic water may be ascribed to the increasing of root 
growth and stomata conductance which increase absorption and assimilation of nutrients as reported by Takashenko (1995).

The effect of types of irrigation water (magnetized and non-magnetized water) under different levels of $\mathrm{N}$ fertilizer on shoot length and root length in the late growth stages of cowpea. Length of shoots and roots determined in wet and dry bases to make sure the obtained data. High shoots and roots length were obtained with plants irrigated by magnetized water under different levels of $\mathrm{N}$ fertilizer, while low length of shoots and roots were obtained with plants irrigated by non-magnetized water under different levels of $\mathrm{N}$ fertilizer in both growing seasons.

Effect of using different levels of $\mathrm{N}$ chemical fertilization on the vegetative growth parameters of cowpea plants are presented in Table 4. The results showed a significant increase in the values of all vegetative growth parameters with each increase in nitrogen chemical fertilization level from $75 \% \mathrm{~N}$ to $100 \% \mathrm{~N}$ when plants irrigated with magnetized water as compared with those plants irrigated with untreated water in both seasons. These findings agree with those obtained by Seran and Imthiyas (2016) and Jayasinghe and Weerawansh (2018) in tomato plants. Sainju et al., (2003) stated that N deficiency reduced dry matter and leaf area and resulted in fewer leaflets that provide less light interception and a lower rate of photosynthesis. In this respect, it is known that $\mathrm{N}$ is an essential element in biosynthesis of amino acids, nucleic acids, protein, formation of protoplasm and new cells.

These results indicated that the treatment combination of magnetic water with $75 \% \mathrm{~N}$ fertilizer, which did not significantly differ from magnetic water with $100 \% \mathrm{~N}$ fertilizer, may leads to an increase in the efficiency of nitrogen fertilizer and a saving in the amount used by at least $25 \%$ without any deterioration in the vegetative growth characters. The obtained results are in harmony with many studies carried out by Abou El-Yazied et al., (2012), Aman and Rab (2013) and Dawa et al., (2017). These authors confirmed the possibility of rationalizing chemical fertilizers by about $25 \%$ without affecting the vegetative growth characters of cowpea plants. Also, Abd El-Latif et al., (2015) approved the possibility of reducing chemical fertilization rates to $50 \%$ by using magnetized water on strawberry plants. In this regard, the enhancement of growth due to magnetic treatments at the lowest level of fertilization may be attributed to the physiochemical changes of natural water by weakling the hydrogen bonds between water molecules which leads to reduce surface tension, increase minerals dissolvability and providing adequate nutrients for plant growth, development of roots and shoots (Takashenko, 1995). Selim et al., (2009) recorded that the increased in growth may be attributed to the increment in absorption of essential element, production of photosynthesis enzyme activities, synthesis of phytohormpnes gibberellic acid (GA3), indole acetic acid (IAA) and cytokinin as well as reduce abscisic acid (ABA).

The interaction effects between types of irrigation water (magnetized and non-magnetized water) and different levels of nitrogen chemical fertilizer significantly affected the vegetative growth parameters in both growing seasons Table 4 . The highest values were recorded when using magnetic water combined with the highest level (100\%) of $\mathrm{N}$ fertilizer. However, the 
lowest values were gained when applied the treatment combination of non-magnetic water with $75 \%$ treatment of $\mathrm{N}$ fertilizer.

Table 4: Means of growth parameters of cowpea plants as affected by the interaction between types of irrigation water (magnetized and non-magnetic water) and nitrogen levels during summer seasons of 2018 and 2019.

\begin{tabular}{|c|c|c|c|c|c|c|c|}
\hline \multicolumn{2}{|c|}{$\begin{array}{l}\text { Treatments } \\
\text { characters }\end{array}$} & \multicolumn{2}{|c|}{$\begin{array}{l}\text { Shoot length } \\
\mathrm{cm}\end{array}$} & \multicolumn{2}{|c|}{$\begin{array}{l}\text { Root length } \\
\mathrm{cm}\end{array}$} & \multicolumn{2}{|c|}{$\begin{array}{c}\text { Cowpea yield } \\
\mathrm{kg} / \mathrm{ha}\end{array}$} \\
\hline $\begin{array}{l}\text { Irrigation } \\
\text { water type }\end{array}$ & $\mathrm{N}$ levels & 2018 & 2019 & 2018 & 2019 & 2018 & 2019 \\
\hline \multirow{2}{*}{$\begin{array}{l}\text { Magnetic } \\
\text { water }\end{array}$} & $\begin{array}{c}100 \% \\
\mathrm{~N}\end{array}$ & $61.8 \mathrm{a}$ & $63.8 \mathrm{a}$ & $34.35 \mathrm{a}$ & $26.91 \mathrm{bc}$ & $2870.91 \mathrm{a}$ & $2980.25 \mathrm{a}$ \\
\hline & $75 \% \mathrm{~N}$ & $60.6 \mathrm{a}$ & $58.5 \mathrm{~b}$ & $30.00 \mathrm{ab}$ & $31.59 \mathrm{a}$ & $2870.00 \mathrm{a}$ & $2880.69 \mathrm{a}$ \\
\hline \multirow{2}{*}{$\begin{array}{c}\text { Non- } \\
\text { magnetic } \\
\text { water }\end{array}$} & $\begin{array}{c}100 \% \\
\mathrm{~N}\end{array}$ & $54.0 \mathrm{~b}$ & $54.0 \mathrm{bc}$ & $27.48 \mathrm{bc}$ & $23.00 \mathrm{c}$ & $2278.50 \mathrm{~b}$ & $2275.00 \mathrm{~b}$ \\
\hline & $75 \% \mathrm{~N}$ & $53.0 \mathrm{~b}$ & $50.0 \mathrm{c}$ & $24.00 \mathrm{c}$ & $27.00 \mathrm{~b}$ & $2277.80 \mathrm{~b}$ & $2199.00 \mathrm{~b}$ \\
\hline \multicolumn{2}{|c|}{$\begin{array}{l}\text { Treatments } \\
\text { characters }\end{array}$} & \multicolumn{3}{|c|}{$\begin{array}{c}\text { Root dry weight } \\
\mathrm{kg} / \mathrm{ha}\end{array}$} & \multicolumn{3}{|c|}{$\begin{array}{c}\text { Shoot dry weight } \\
\mathrm{kg} / \mathrm{ha}\end{array}$} \\
\hline $\begin{array}{l}\text { Irrigation } \\
\text { water type }\end{array}$ & $\mathrm{N}$ levels & & & 2019 & 2018 & & 2019 \\
\hline \multirow{2}{*}{$\begin{array}{l}\text { Magnetic } \\
\text { water }\end{array}$} & $100 \% \mathrm{~N}$ & \multicolumn{2}{|c|}{$1122.2 \mathrm{a}$} & $1098.3 \mathrm{a}$ & 8416.7 & \multicolumn{2}{|c|}{$5216.7 \mathrm{a}$} \\
\hline & $75 \% \mathrm{~N}$ & \multicolumn{2}{|c|}{$1022.2 \mathrm{~b}$} & $1033.3 \mathrm{~b}$ & 7561.1 & \multicolumn{2}{|c|}{$5191.7 \mathrm{~b}$} \\
\hline \multirow{2}{*}{$\begin{array}{c}\text { Non- } \\
\text { magnetic } \\
\text { water }\end{array}$} & $100 \% \mathrm{~N}$ & \multicolumn{2}{|c|}{$984.4 \mathrm{c}$} & $1005.5 \mathrm{c}$ & 5783.3 & \multicolumn{2}{|c|}{$3672.6 \mathrm{c}$} \\
\hline & $75 \% \mathrm{~N}$ & \multicolumn{2}{|c|}{$908.9 \mathrm{~d}$} & $827.8 \mathrm{~d}$ & 3983.3 & \multicolumn{2}{|c|}{$3634.1 \mathrm{~d}$} \\
\hline
\end{tabular}

Means followed by the same letter are not significantly different according to Duncan's multiple range test ( $\mathrm{P}$ at 0.05 level).

\section{The crop yield:}

The results of the effects of types of irrigation water under different levels of nitrogen fertilizer and their interactions on the cowpea yield are listed in Table 4. Concerning the influences of magnetized water, the results reflected that irrigation with magnetic water significantly increased the values of the characters root dry weight, shoot dry weight and total yield as comparing with irrigation using non-magnetic water under different levels of nitrogen fertilizer in both growing seasons. The percentage of increase in total yield at irrigation with magnetic water was 26 and $31 \%$ under different levels of $\mathrm{N}$ fertilizers for the first and second season, respectively, in comparison with non-magnetic water. However, the percentage of increment in root dry weight, shoot dry weight with magnetic water irrigation was from 7 to $21 \%$ for root dry weight and from 42 to $89 \%$ for shoot dry weight for the first and second season, respectively. These results generally, agree with those obtained by Dawa et. al., (2017) on tomato plants. They reported that the irrigation with magnetic water had significant impacts on tomato yield and its components characters. 
Different rates of nitrogen fertilizer significantly affected yield in cowpea plants. Whereas the values for all the previously mentioned treatments significantly increased with an increase in $\mathrm{N}$ rate from $75 \%$ to $100 \% \mathrm{~N}$ when plants irrigated with magnetized water as compared with those plants irrigated with non-magnetic water treatment in the two studied seasons Table 4. These results reflect a general agreement with those obtained by Kumar et al. (2013) and Jayasinghe and Weerawansha (2018) on tomato plants.

Regarding the effects of the interaction between the two types of irrigation water and the two different levels of nitrogen, the obtained results indicate that cowpea plants irrigated with magnetic water combined with $100 \% \mathrm{~N}$ level gave the highest value for all yield treatments without significant differences among the treatment combination of magnetic water with $75 \%$ $\mathrm{N}$, during the two growing seasons. These results reflect the possibility of reducing the rate of nitrogen chemical fertilization when irrigation with magnetized water to a percentage $25 \%$ without affecting the cowpea crop. These results reflected similar trends to those reported by Jawad et al. (2014), Aman and Rab (2013), and Abou El-Yazied et al. (2012), on tomato crop. These results could probably be due to, that the passing of water through a magnetic field increases the number of water molecules in the volume unit and increases the ability of water molecules to absorb nutrients. Magnetic water treatment has found to have a pronounced effect on plants productivity (Teixeira and Dobranszki, 2014). The results are in harmony with El-Sagan and Abd El-Baset (2015) on onion crop. Moreover, Esitken and Turan (2004), recorded positive effects of magnetic field on plant metabolism, such as photosynthesis, hormonal and enzyme activities, and movements to endogenous solute, especially of carbohydrates and hormones transported from regions of synthesis to the fruits and growth zone. In addition, magnetic field influences plant nutrient element uptake from growing media.

\section{Water Use Efficiency (WUE):}

The results of the effects of types of irrigation water under different levels of nitrogen fertilizer and their interactions on water use efficiency (WUE) are listed in Table 5. Concerning the effects of magnetized water, the results reflected that irrigation with magnetic water significantly increased the values of the water use efficiency as comparing with irrigation using non-magnetic water under different levels of nitrogen fertilizer in both growing seasons. The percentage of water use efficiency at irrigation with magnetic water were 0.52 and $0.54 \mathrm{~kg} / \mathrm{m}^{3}$ for the first and second season respectively; in comparison with non-magnetic water were 0.40 and $0.42 \mathrm{~kg} / \mathrm{m}^{3}$. The output of water use efficiency for irrigating cowpea plant under drip irrigation system was calculated using Zhang et al. (2005) said that the water use efficiency (WUE) is the ratio of yield to seasonal crop evapotranspiration (ETc).

\section{Nitrogen uptake and nitrogen use efficiency (NUE, \%):}

Nitrogen uptake by shoot and root of cowpea crop as affected by types of irrigation water under different rates of $\mathrm{N}$ fertilizer was presented in Table 6. Roots nitrogen uptake seems to be significantly positively affected by ammonium sulphate additions where it shows higher $\mathrm{N}$ accumulation with higher $\mathrm{N}$ rate $(100 \%)$ than those recorded with $(75 \%)$. The results showed that a significant increase in the values for all treatments with magnetized water in both seasons. 
Table 5: Means of water use efficiency as affected by the interaction between types of irrigation water (magnetized and non-magnetic water) and nitrogen levels during summer seasons of 2018 and 2019.

\begin{tabular}{|c|c|c|c|c|c|c|c|}
\hline \multicolumn{2}{|c|}{$\begin{array}{c}\text { Treatments } \\
\text { characters }\end{array}$} & \multicolumn{2}{c|}{$\begin{array}{c}\text { Cowpea yield } \\
\mathrm{kg} / \mathrm{ha}\end{array}$} & \multicolumn{2}{c|}{$\begin{array}{c}\text { Total water } \\
\text { applied } \mathrm{m}^{3} / \mathrm{ha}\end{array}$} & \multicolumn{2}{c|}{$\begin{array}{c}\text { Water use } \\
\text { efficiency } \mathrm{kg} / \mathrm{m}^{3}\end{array}$} \\
\hline $\begin{array}{c}\text { Irrigation } \\
\text { water type }\end{array}$ & $\mathrm{N}$ levels & 2018 & 2019 & 2018 & 2019 & 2018 & 2019 \\
\hline \multirow{2}{*}{$\begin{array}{c}\text { Magnetic } \\
\text { water }\end{array}$} & $100 \% \mathrm{~N}$ & $2870.9 \mathrm{a}$ & $2980.25 \mathrm{a}$ & 5430 & 5430 & $0.52 \mathrm{a}$ & $0.54 \mathrm{a}$ \\
\cline { 2 - 8 } & $75 \% \mathrm{~N}$ & $2870.0 \mathrm{a}$ & $2880.69 \mathrm{a}$ & 5430 & 5430 & $0.52 \mathrm{a}$ & $0.53 \mathrm{a}$ \\
\hline $\begin{array}{c}\text { Non- } \\
\text { magnetic } \\
\text { water }\end{array}$ & $100 \% \mathrm{~N}$ & $2278.5 \mathrm{~b}$ & $2275.00 \mathrm{~b}$ & 5430 & 5430 & $0.42 \mathrm{~b}$ & $0.41 \mathrm{~b}$ \\
\cline { 2 - 8 } & $75 \% \mathrm{~N}$ & $2277.8 \mathrm{~b}$ & $2199.00 \mathrm{~b}$ & 5430 & 5430 & $0.42 \mathrm{~b}$ & $0.40 \mathrm{~b}$ \\
\hline
\end{tabular}

Means followed by the same letter are not significantly different according to Duncan's multiple range test ( $\mathrm{P}$ at 0.05 level).

Table 6: Nitrogen uptake ( $\mathrm{kg} / \mathrm{ha})$ as affected by the interaction between types of irrigation water (magnetized and non-magnetic water) and nitrogen levels during summer seasons of 2018 and 2019.

\begin{tabular}{|c|c|c|c|c|c|c|c|}
\hline \multicolumn{2}{|c|}{ Treatments characters } & \multicolumn{2}{c|}{ Root } & \multicolumn{2}{c|}{ Shoot } & \multicolumn{2}{c|}{ Seeds } \\
\hline $\begin{array}{c}\text { Irrigation water } \\
\text { type }\end{array}$ & $\mathrm{N}$ levels & 2018 & 2019 & 2018 & 2019 & 2018 & 2019 \\
\hline \multirow{2}{*}{\begin{tabular}{c} 
Magnetic water \\
\cline { 2 - 8 }
\end{tabular}} & $100 \% \mathrm{~N}$ & $11.37 \mathrm{a}$ & $12.22 \mathrm{a}$ & $76.96 \mathrm{a}$ & $100.17 \mathrm{a}$ & $52.87 \mathrm{a}$ & $62.15 \mathrm{a}$ \\
\hline \multirow{2}{*}{$\begin{array}{c}\text { Non-magnetic } \\
\text { water }\end{array}$} & $100 \% \mathrm{~N}$ & $9.34 \mathrm{~b}$ & $9.71 \mathrm{~b}$ & $69.63 \mathrm{~b}$ & $96.69 \mathrm{~b}$ & $49.11 \mathrm{a}$ & $55.15 \mathrm{a}$ \\
\cline { 2 - 8 } & $75 \% \mathrm{~N}$ & $6.96 \mathrm{~d}$ & $8.47 \mathrm{~d}$ & $31.21 \mathrm{~d}$ & $37.61 \mathrm{~d}$ & $38.03 \mathrm{~b}$ & $43.07 \mathrm{~b}$ \\
\hline
\end{tabular}

Means followed by the same letter are not significantly different according to Duncan's multiple range test ( $\mathrm{P}$ at 0.05 level).

Concerning nitrogen uptake by shoot, similar trends, in general, that $\mathrm{N}$ uptake by shoot was significantly higher than those recorded with root or seeds. Nitrogen uptake by cowpea seeds was significantly positively affected by irrigation regime as detected by overall means which recorded 52.87 and $62.15 \mathrm{~kg} \mathrm{~N} / \mathrm{ha}$ under $(100 \% \mathrm{~N})$ with plants irrigated with magnetized water against 38.87 and $51.33 \mathrm{~kg} \mathrm{~N} / \mathrm{ha}$ under $(100 \% \mathrm{~N})$ with plants irrigated with nonmagnetic water in both growing seasons. Fertilization with ammonium sulphate at $100 \%$ rate induced higher $\mathrm{N}$ uptake by seeds than those of $75 \%$ rate in both seasons. Seeds of cowpea crop irrigated with magnetized water derived more nitrogen from fertilizer source as compared to non-magnetic water. $\mathrm{N}$ derived from $100 \%$ ammonium sulphate fertilizer was higher than those derived from $75 \%$ ammonium sulphate rate.

Significant variations in nitrogen uptake and nitrogen use efficiency (NUE, \%) were obviously due to types of irrigation water. Irrigation with magnetized water gave significantly 
superior values of nitrogen uptake and nitrogen use efficiency than irrigation with nonmagnetized water in both seasons of 2018 and 2019 Tables 6 and 7. The results showed that a significant increase in the values for all traits with magnetized water in both growing seasons. On the other hand, various levels of $\mathrm{N}$ fertilizer treatments reflected a significant positive effect on treatments. The highest level of Nitrogen (100\%) produced significantly higher values for all treatments. A gradual significant increase in the values was also observed with an increase in the $\mathrm{N}$ fertilizer level. These results reflected similar trends to those reported by Seran and Imthiyas (2016) on tomato.

As described above with nitrogen derived from fertilizer, nitrogen was efficiently used by seeds of cowpea plants irrigated with magnetized water as compared to irrigated with nonmagnetic water (Table 7). On the basis of overall mean, plants irrigated with magnetized water achieved 65.15 NUE, \% against 45.05 NUE\% detected with plants irrigated with nonmagnetic water.

Table 7: Nitrogen use efficiency (NUE, \%) as affected by the interaction between types of irrigation water (magnetized and non-magnetic water) and nitrogen levels during summer seasons of 2018 and 2019.

\begin{tabular}{|c|c|c|c|c|c|c|c|}
\hline \multicolumn{2}{|c|}{$\begin{array}{c}\text { Treatments } \\
\text { characters }\end{array}$} & \multicolumn{2}{c|}{ Root } & \multicolumn{2}{c|}{ Shoot } & \multicolumn{2}{c|}{ Seeds } \\
\hline $\begin{array}{c}\text { Irrigation } \\
\text { water type }\end{array}$ & N levels & 2018 & 2019 & 2018 & 2019 & 2018 & 2019 \\
\hline $\begin{array}{c}\text { Magnetic } \\
\text { water }\end{array}$ & $100 \% \mathrm{~N}$ & $9.65 \mathrm{a}$ & $11.75 \mathrm{a}$ & $81.15 \mathrm{a}$ & $86.25 \mathrm{a}$ & $65.15 \mathrm{a}$ & $66.75 \mathrm{a}$ \\
\cline { 2 - 8 } & $75 \% \mathrm{~N}$ & $9.15 \mathrm{a}$ & $10.35 \mathrm{a}$ & $77.75 \mathrm{~b}$ & $80.05 \mathrm{~b}$ & $59.75 \mathrm{~b}$ & $64.85 \mathrm{a}$ \\
\hline $\begin{array}{c}\text { Non- } \\
\text { magnetic } \\
\text { water }\end{array}$ & $100 \% \mathrm{~N}$ & $6.55 \mathrm{~b}$ & $7.35 \mathrm{~b}$ & $59.15 \mathrm{c}$ & $72.55 \mathrm{c}$ & $45.05 \mathrm{c}$ & $49.95 \mathrm{~b}$ \\
\cline { 2 - 8 } & $75 \% \mathrm{~N}$ & $5.75 \mathrm{~b}$ & $6.25 \mathrm{~b}$ & $29.75 \mathrm{~d}$ & $35.15 \mathrm{~d}$ & $44.55 \mathrm{c}$ & $47.15 \mathrm{c}$ \\
\hline
\end{tabular}

Means followed by the same letter are not significantly different according to Duncan's multiple range test ( $\mathrm{P}$ at 0.05 level).

In general, NUE, \% by shoots seems to be higher than those recorded with seeds. In this respect, NUE, \% by shoots tended to increase with plants irrigated with magnetized water as compared to plants irrigated with non-magnetic water under different rates of $\mathrm{N}$ fertilizer. On the other hand, it declines with reduction in nitrogen fertilizer rate. In case of root system, the efficient use of both fertilizer levels was significantly positively affected by types of irrigation water.

The above mentioned results indicated the importance of types of irrigation water and nitrogen fertilizer management practices on enhancement or depressing of nutrient uptake by cowpea plant. In other turn, proper management of both water and nutrients, in general, could be considered as mean followed to achieve remarkable production with low costs and without environmental risks. Enhancement of nitrogen use efficiency may reduce the losses via leaching or any other mechanisms.

These results, generally, illustrated that the addition of nitrogen fertilizer, as $100 \% \mathrm{~N}$ of recommended rate, combined with magnetic water, resulted in the highest values in all the 
above mentioned treatments without significant differences among the treatments combination of magnetic water with $75 \% \mathrm{~N}$, during the two growing seasons and confirmed the possibility of increase efficiency of $\mathrm{N}$ fertilizer and saving the amount used by $25 \%$ without notable negative effects. These results reflected similar trends of the finding of ElSagan and Abd El-Baset, (2015), Jawad et.al. (2014) and Abou El-Yazied et al. (2012) on tomato plant, through the results it becomes clear that the levels of chemical fertilization $\mathrm{N}$ can be rationalized up to $25 \%$ by irrigation with magnetized water without affecting the growth parameters and yield of pea.

\section{CONCLUSIONS}

This study indicated that applying of magnetized water irrigation as a new environmentally friendly technology, lead to several advantages for cowpea plants such as enhancing vegetative growth, increasing yield, improving water use efficiency and nitrogen use efficiency. The interaction effects of types of irrigation water (magnetized and nonmagnetized) and different levels of nitrogen chemical fertilizer significantly affected all studied treatments and reflected a positive impact. These were presented by possibility of reducing the rates of nitrogen chemical fertilizer used for the optimal growth and productivity of cowpea by $25 \%$ without compromising the quantity or quality of cowpea yield, which lead to reducing the cost of farm operations and reducing environmental pollution resulting from excessive use of such fertilizers.

\section{REFERENCES}

Abd El-Latif A., A. Abdelshafy and T. Eid, (2015). Minimizing strawberry mineral fertilization and enhancing water use efficiency by using magnetized irrigation water. Journal of Plant Production, 6(9): 1581-1593.

Abou El-Yazied, A., A.M. El-Gizawy, S.M. Khalf, A. El-Satar and O.A. Shalaby, (2012). Effect of magnetic field treatments for seeds and irrigation water as well as $\mathrm{N}, \mathrm{P}$ and $\mathrm{K}$ levels on productivity of tomato plants. Journal of Applied Sciences Research, 8(4): 2088-2099.

Ali, Y., R. Samaneh and F. Kavakebian, (2014). Applications of magnetic water technology in farming and agriculture development: A review of recent advances. Current World Environment, 9(3):695-703.

Anele, U. Y, K. H. Sudekum, J. Hummel, O. M. Arigbede, A. O. Oni, J. A. Olanite, C. Bottger, V. O. Ojo, A. O. Jolaosho (2011). Chemical characterization, in vitro dry matter and ruminal crude protein degradability and microbial protein synthesis of some cowpea (Vigna unguiculata L. Walp) haulm varieties. Anim. Feed Sci. Technol., 163 (2-4), 161-169.

Aman, S. and A. Rab, (2013). Response of tomato to nitrogen levels with or without humic Acid. In Sarhad Journal Agriculture, 29(2):181-187.

Amer, M. N, A. G. El-Sanat and S. H. Rashad (2014). Effects of magnetized low quality irrigation water on some soil properties and soybean yield (Glycine max L.) under salt affected soils conditions. J. Soil Sci.and Agric. Eng., Mansoura Univ. 5 (10), 1377 1388 .

Bashandy, T. and A.A. H. El-Shaieny (2016). Screening of Cowpea (Vigna unguiculata L. Walp) genotypes for salinity tolerance using field evaluation and molecular analysis. J. 
Agric. Chem. And Biotechn. Mansoura Univ. 7 (9), 249-255.

Dawa, K.; H. Abd El-Nabi and W. Swelam (2017). Response of tomato plants to irrigation with magnetized water and some foliar application treatments under drip irrigation system: 1-Vegetative growth and chemical constituents of leaves. Journal of Plant Production, 8(11): 1127-1133.

El-Sagan, M.A.M. and A. Abd El-Baset, (2015). Impact of magnetic on metal uptake, quality and productivity in onion crop. IOSR Journal of Agriculture and Veterinary Science, 8(9): 2319-2372.

Esitken, A. and Turan, M. (2004). Alternating magnetic field effects on yield and plant nutrient element composition of strawberry (Fragaria x ananassa cv. camarosa). Acta Agric. Scand., Sect. B, Soil and Plant Sci. 54: 135-139.

Gonçalves, A, P. Goufo, A. Barros, R. Domínguez- Perles, H. Trindade, E. Rosa, L.Ferreira and M. Rodrigues (2016). Cowpea (Vigna unguiculata L. Walp), a renewed multipurpose crop for a more sustainable agri-food system: nutritional advantages and constraints. Journal of the Science of Food and Agriculture, 96: 2941-2951.

Hozayn, M., A.A. Abdel-Monem and A.M.S.A. Qados, (2011). Irrigation with magnetized water, a novel tool for improving crop production in Egypt. World Environmental and Water Resources Congress 2011: Bearing Knowledge for Sustainability - Proceedings of the 2011 World Environmental and Water Resources Congress, 4206-4222.

Jawad, A.T., H. A. Abbas, S. N. Abdullah, A.A. Abid Uon, S.A. Muhi, R.I. Jaafar and O.A. Musluh, (2014). The Effect of Magnetic Water for Chemical Fertilizer in Tomato Plant. Baghdad Science Journal, 11(2): 958-961.

Jayasinghe, H. and A. Weerawansha, (2018). Effect of compost and different NPK Levels on growth and yield of three tomato (Solanum lycopersicum) varieties in Sri Lanka. Journal of Advanced Agricultural Technologies, 5(2): 129-133.

Klute, A. (1986) Methods of soil analysis. Part 1. Physical and mineralogical methods (2nd edition). American Society of Agronomy Inc., Madison, Wisconsin, USA.

Kumar, M., M.L. Meena, S.S. Kumar, S.S. Maji and D. Kumar (2013). Effect of nitrogen, phosphorus and potassium fertilizers on the growth, yield and quality of tomato var. Azad T-6. The Asian Journal of Horticulture, 8(2): 616-619.

Maheshwari, B.L. and H.S. Grewal, (2009). Magnetic treatment of irrigation water: Its effects on vegetable crop yield and water productivity. Agricultural Water Management, 96(8): 1229-1236.

Ministry of Agriculture and Land Reclamation, Economic Affairs Sector (MALR) (2019). Bulletin of the agricultural statistics, Part 2. 382pp, Egypt.

Moussa, H.R. (2011) The impact of magnetic water application for improving common bean (Phaseolus vulgaris L.) production. New York Sci J, 4, 15-20.

Omid, S. (2016). The effect of magnetized water on physiological and agronomic traits of cowpea (Vigna unguiculata L.). Int'l Journal of Research in Chemical, Metallurgical and Civil Eng. 3 (2), 195 -198.

Page, A., R. Miller and D. Keeny, (1982). Methods of Soil Analysis, Part 2: Chemical and Microbiological Properties. American Society of Agronomy. Madison, Wi., USA.

Sadeghipour, O., P. Aghaei and O. Sadeghipour, (2013). Improving the growth of 
cowpea (Vigna unguiculata L. walp.) by magnetized water. Journal of Biodiversity and Environmental Sciences, 3(1): 37-43.

Sainju, U.M., R.R. Dris and B. Singh, (2003). Mineral nutrition of tomato. Food, Agriculture and Environment, 1(2): 176-184.

Selim, Dalia A., A.A. Gendy, A.M Maria and E.M. Mousa, (2009). Response of pepper plants to magnetic technologies. In: 1st Nile Delta Conf. on Export Crops Faculty of Agriculture Minufiya University, pp. 89-104.

Selim, M.M., (2008). Application of magnetic technologies in correcting underground brackish water for irrigation in the arid and semi-arid ecosystem. The 3rd International Conference on Water Resources and Arid Environments, and the 1st Arab Water Forum, held at King Fahd Cultural Centre in Riyadh, Saudi Arabia: 1-11.

Seran, T.H. and M.S.M. Imthiyas, (2016). Effect of different doses of NK chemical fertilizers and compost on growth and yield attributes of tomato (Lycopersicon esculentum Mill.). Turkish Journal of Agriculture - Food Science and Technology, 4(6): 481-485.

Shahin, M. M. and A.M.A. Mashhour, (2016). Effect of magnetized irrigation water and seeds on some water properties, growth parameter and yield productivity of cucumber plants. Current Science International, 5(2): 152-164.

Shedeed, S.I.; S.M. Zaghloul and A.A. Yassen, (2009). Effect of method and rate of fertilizer application under drip irrigation on yield and nutrient uptake by tomato. Ozean Journal of Applied Sciences, 2(2): 139-147.

Takashenko, Y. (1995). The application of magnetic technology in agriculture (Magnetizer). Abu- Dhabi, UAE.

Teixeira da Silva, J.A. and J. Dobránszki, (2014). Impact of magnetic water on plant growth. Enviromental and Experimental Biology, 12(4): 137-142.

Waller, R. A. and D. B. Duncan, (1969). A bays rule for the symmetric multiple comparison problem. Journal of the American Statistical Association. No. 64: 1485-1504.

Wang HY and Zhou JM. (2014). Calculation of real fertilizer use efficiency and discussion on fertilization strategies. Acta Pedologica Sinica. 2014;51(2):10-9.

Yadollahpour, A, S. Rashidi and K. Fatemeh. (2014). Applications of magnetic water technology in farming and agriculture development: A Review of recent advances. Current World Envir. 9 (3), 695-703.

Yusuf, K.O. and A.O. Ogunlela, (2015). Impact of magnetic treatment of irrigation water on the growth and yield of tomato. Notulae Scientia Biologicae, 7 (3): 345-348.

Yusuf, K.O. and A.O. Ogunlela, (2017a). Effects of magnetized water on the vegetative growth and yield of tomato. Agricultural Engineering International CIGR Journal, 19(1): 1-8.

Yusuf, K.O. and A.O. Ogunlela, (2017b). Effects of deficit irrigation on the growth and yield of tomato (Solanum lycopersicum) irrigated with magnetized water. Environmental Research Engineering and Management, 73(1): 59-68.

Zhang, X.; S. Chen; M. Liu; D. Pei and H. Sun (2005). Improved water use efficiency associated with cultivars and agronomic management in the north China plain. Agronomy J. 97:783-790. 
تأثير مياه الري والتسميد النيتروجيني على النمو والإنتاجية لمحصول اللوبيا مع الماء الممغتط

عبد التواب متولي ابراهيم زيدان' ، أحمد فتحي محمد خضر \ و محمد أبو زيد رشاد؟

' أستاذ مساعد هندسة الري والصرف ـ قسم الهندسة الزر اعية ـ كلية الزر اعة ـ جامعة الزقازيق ـ مصر.

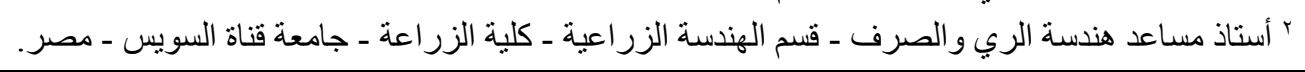

\begin{tabular}{|c|c|}
\hline الملخص العربي & \\
\hline أظهر استخدام المياه الممغنطة العديد من المزايا بما في ذلك تحسين جودة مياه & \\
\hline الري وزيادة إنتاجية محاصيل الخضار . لذلك، تم تتفيذ هذا العمل لدر اسة استجابة & \\
\hline النمو، و المحصول، وكفاءة استخدام المياه وكفاءة استخدام النيتروجين من اللوبيا & \\
\hline مع الري بنو عين من مياه الري (المياه الممغنطة و غير الممغنطة) تحت مستويين & \\
\hline 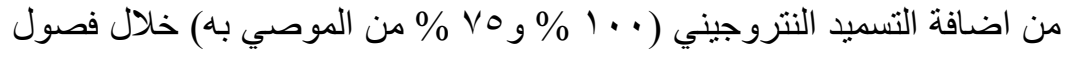 & \\
\hline 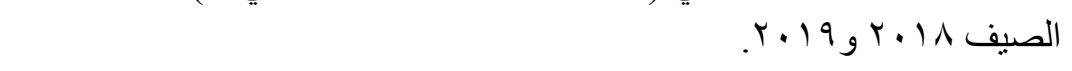 & \\
\hline اثبتت النتائج أن جميع خصائص المحصول ارتفعت بشكل ملحوظ عندما ثم الري & \\
\hline باستخدام المياه الممغنطة، مثل إجمالي المحصول الذي يزيد بحوالي جب و آ؟\% & \\
\hline في كلا الموسمين على التوالي، وباستخدام الري بالمياه الممغنطة ادت الى زيادة & \\
\hline 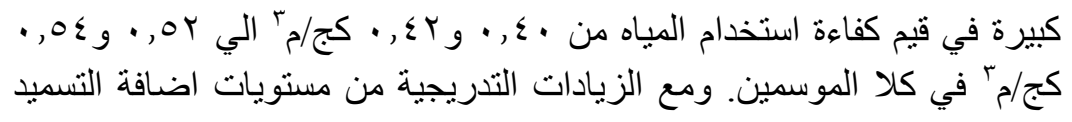 & 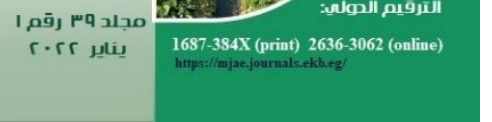 \\
\hline كزالنتروجيني ادت الي زيادة كبيرة في النمو والاستفادة من النيتروجين وزيادة & 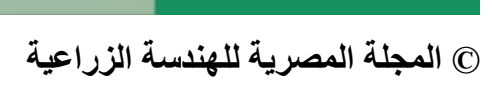 \\
\hline 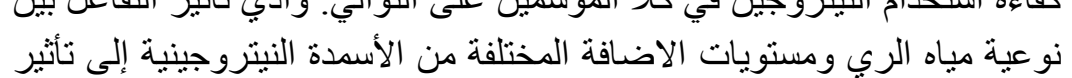 & \\
\hline كبير وايجابي على جميع المعاملات. وتعكس النتائج إمكانية تخفيض معدل & 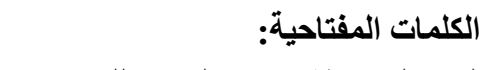 \\
\hline الاضافة من التسميد النيتروجيني بمعدل هץ\% عندما تروي نباتات اللوبيا بالمياه & المياه الممغنطة؛ جودة المياه، اللوبيا؛ \\
\hline الممغنطة دون التأثير على الخصائص المحصولية المختلفة. وكذلك العديد من & خصائص النمو؛ كفاءة استخدام المباه \\
\hline الفوائد لمحصول اللوبيا مثل تعزيز النمو الخضري، وزيادة المحصول، وتحسين & و النيترو جين. \\
\hline نو عيتها. & \\
\hline
\end{tabular}

